\title{
HUBUNGAN KEBIASAAN MAKAN DENGAN KEJADIAN OSTEOPOROSIS PADA LANSIA DI PUSKESMAS KUTALIMBARU KECAMATAN KUTALIMBARU KABUPATEN DELI SERDANG
}

\author{
Relationship Habits With Osteoporosis Events at Lansia In Kutalimbaru \\ Public Health Center District Deli Serdang
}

\author{
Purwaningsih $^{1}$, Ade Irma Khairani ${ }^{1}$ \\ ${ }^{1}$ Dosen Tetap Akademi Keperawatan Kesdam I/Bukit Barisan Medan \\ Email : purwaningsihmkm@gmail.com, manurungade@ gmail.com
}

\begin{abstract}
Abstrak
Berdasarkan data World Health Organization (WHO) osteoporosis masuk dalam daftar 10 penyakit degeneratif utama di dunia. Terdapat \pm 200 juta pasien di seluruh dunia yang menderita osteoporosis. Di Indonesia 19,7\% dari jumlah lansia atau sekitar 3,6 juta orang di antaranya menderita osteoporosis. Meningkatnya insidensi osteoporosis dihubungkan dengan bertambahnya usia dan kebiasaan makan yang kurang baik. Tujuan penelitian ini untuk menganalisis hubungan kebiasaan makan dengan osteoporosis pada lansia.

Penelitian ini adalah penelitian analitik dengan pendekatan case control. Penelitian dilakukan di Puskesmas Kutalimbaru Kabupaten Deli Serdang. Populasi dalam penelitian ini sebanyak 190 orang. Sampel dibagi dalam 2 kelompok (masing-masing kelompok 95 orang). Analisis dilakukan secara univariat, bivariat menggunakan chi-square dan multivariat menggunakan regresi logistik berganda. Hasil penelitian menunjukkan bahwa kebiasaan makan sehari-hari lansia yang berhubungan signifikan dengan kejadian osteoporosis di Puskesmas Kutalimbaru Kecamatan Kutalimbaru Kabupaten Deli Serdang yaitu porsi makan $(p=0,005$, OR $=3,374)$, konsumsi kopi $(p=0,000$, $\mathrm{OR}=4,116)$, dan konsumsi sayuran hijau $(p=0,013, \mathrm{OR}=2,399)$. Sedangkan variabel yang tidak berhubungan dengan osteoporosis pada lansia adalah minum air putih $(p=0,512)$, konsumsi susu $(p=0,094)$, dan konsumsi buah segar $(p=0,385)$. Variabel yang paling besar berhubungan dengan osteoporosis pada lansia yaitu konsumsi kopi. Lansia yang sering mengonsumsi kopi berpeluang mengalami osteoporosis sebesar 4,1 kali lebih tinggi dibandingkan dengan lansia yang jarang atau tidak pernah mengonsumsi kopi.

Kesimpulan penelitian ini osteoporosis pada lansia berhubungan dengan porsi makan, konsumsi kopi, dan konsumsi sayuran hijau. Disarankan kepada Puskesmas Kutalimbaru untuk memberikan penyuluhan atau promosi kesehatan tentang kadarzi (keluarga sadar gizi) pada masyarakat dengan sasaran lansia melalui kegiatan-kegiatan kemasyarakatan seperti perwiritan, perpulungan, atau arisan keluarga
\end{abstract}

Kata Kunci: Kebiasaan Makan, Osteoporosis, Lansia

\begin{abstract}
Based on WHO data, osteoporosis is classified into 10 main degenerative diseases in the world there are \pm 2000 million patients in the world with osteoporosis. In Indonesia, $19.7 \%$ of the elderly or 3.6 million of people with osteoporosis. The increasing of incident of osteoporosis is related to the age and bad eating habits. The objective of this research is to analyze a correlation between the eating habit and osteoporosis to the elderly.

This research was an analytic study with case control approach. This research was conducted in Puskesmas Kutalimbaru Regency of Deli Serdang. The population of this research were 190 persons. The sample was divided into 2 group (each group is consist of 95 persons). The analysis was univariable, bivariable using chi square and multi variable using multi logistic regression.

The result of research indicates that the eating habit of elderly was related to the incident of osteoporosis significantly in Puskesmas Kutalimbaru sub district of Kutalimbaru, Regency of Deli Serdang, diet portion $(\mathrm{p}=0.005, \mathrm{OR}=3.374)$, coffee consumption $(\mathrm{p}=0.000, \mathrm{OR}=4.116)$ and green vegetables consumption $(\mathrm{p} ;=0.013$, OR $=2.399)$. while variable that did not related to the osteoporosis to the elderly was water drink $(\mathrm{p}=0.512)$, milk consumption $(\mathrm{p}=0.094)$ and fresh fruit consumption $(\mathrm{p}=0.385)$. the dominant variable related to the osteoporosis to the elderly was coffee consumption. The elderly who always consume coffee has a risk for osteoporosis 4.1 higher than elderly who did not or never consume coffee.

The conclusion of this research is the osteoporosis to the elderly is related to the diet portion, consumption of coffee and green vegetables. It is suggested to the Puskesmas Kutalimbaru to provide
\end{abstract}


the extension of health promotion about the nutrition content to the society with the target of elderly through society activities such as society gathering or religion gathering.

Keywords : Eating Habit, Osteoporosis, Elderly

\section{PENDAHULUAN}

Masa usia lanjut merupakan periode penutup dalam rentang hidup kesehatan reproduksi. Semakin bertambahnya usia, secara umum kekuatan dan kualitas fisik juga fungsinya mulai terjadi penurunan. Penurunan ini bisa berlangsung secara perlahan bahkan bisa terjadi secara cepat tergantung dari kebiasaan hidup pada masa usia muda. Seiring dengan peningkatan usia dan proses penuaan, banyak terjadi proses perkembangan dan pertumbuhan pada manusia. Namun pada suatu saat perkembangan dan pertumbuhan itu akan terhenti pada suatu tahapan sehingga berikutnya akan terjadi banyak perubahan yang terjadi pada fungsi tubuh manusia. Proses menua (aging) di dalam perjalanan hidup manusia merupakan suatu hal wajar yang akan dialami semua orang yang dikaruniai umur panjang. Proses menua adalah suatu proses menghilangnya secara perlahan-lahan kemampuan jaringan untuk memperbaiki diri atau mengganti dan mempertahankan fungsi normalnya sehingga tidak dapat bertahan terhadap infeksi dan memperbaiki kerusakan yang diderita. Seiring dengan peningkatan kualitas hidup maka pertumbuhan penduduk lanjut usia (lansia) juga mengalami peningkatan (Hasibuan, 2006).

Badan dunia yang menangani masalah kesehatan, World Health Organization (WHO) memperkirakan tahun 2025 jumlah lansia di seluruh dunia akan mencapai 1,2 miliar orang yang akan terus bertambah hingga 2 miliar orang di tahun 2050. Data WHO juga memperkirakan $75 \%$ populasi lansia di dunia pada tahun 2025 berada di negara berkembang (Wardhana, 2012).

Peningkatan pertumbuhan penduduk lansia di Indonesia mulai dirasakan sejak tahun 2000 yaitu dengan persentase populasi lansia $7,18 \%$ dengan usia harapan hidup 64,5 tahun. Angka ini meningkat menjadi 69, 43 tahun pada tahun 2010 dengan persentase populasi lansia adalah $7,56 \%$, dan pada tahun 2011 menjadi 69,65 tahun dengan persentase populasi lansia adalah $7,58 \%$ (Tami, 2012).

Berdasarkan data Pusat Statistik tahun 2014 bahwa jumlah penduduk lansia yang berumur 60 tahun ke atas di Indonesia sebanyak 15.454 .360 jiwa. Jumlah penduduk lansia terbanyak di Provinsi Jawa Timur sebanyak 3.520.927 jiwa, selanjutnya Jawa Tengah sebanyak 3.131.514 jiwa dan Jawa Barat sebanyak 2.739.719 jiwa (BPS, 2014).

Berdasarkan studi tentang kondisi sosial ekonomi dan kesehatan lanjut usia yang dilaksanakan Komnas Lansia di 10 propinsi tahun 2010, diketahui bahwa penyakit terbanyak yang diderita lansia adalah penyakit sendi termasuk osteoporosis $(52,3 \%)$, dan hipertensi $(38,8 \%)$, anemia $(30,7 \%)$ dan katarak (23\%). Penyakit-penyakit tersebut merupakan penyebab utama disabilitas pada lansia (Komnas Lansia, 2010).

Jumlah penduduk lansia di Provinsi Sumatera Utara tercatat sebanyak 631.604 jiwa. Jumlah lansia dengan keadaan baik sebanyak 242.999 jiwa, keadaan cukup sebanyak 215.787 jiwa dan keadaan kurang sebanyak 172.818 jiwa. Berdasarkan data kabupaten/kota bahwa jumlah tertinggi lansia yaitu di Kota Medan sebanyak 77.837 jiwa, sedangkan jumlah terendah di Kabupaten Pakpak Bharat sebanyak 1.864 jiwa (BPS, 2014).

Berdasarkan data Badan Pusat Statistik tahun 2014 bahwa jumlah lansia di Kabupaten Deli Serdang sebanyak 61.108 jiwa dan menempati urutan keempat terbanyak jumlah lansia di Provinsi Sumatera Utara setelah Medan, Simalungun, Asahan (BPS, 2014). Jumlah lansia dengan keadaan baik sebanyak 21.703 jiwa, keadaan cukup sebanyak 19.222 jiwa dan keadaan kurang sebanyak 20.183 jiwa. Tingginya jumlah penduduk tersebut juga akan 
berpengaruh terhadap masalah kesehatan lansia (Komnas Lansia, 2010).

Fakta dari lembaga National Osteoporosis Foundation di Amerika menunjukkan hasil yang memprihatinkan. Lebih dari 1,5 juta orang di Amerika menderita tulang patah setiap tahunnya yang diakibatkan oleh osteoporosis dan hampir 34 juta orang lainnya diperkirakan mengalami kerendahan densitas tulang (kerapuhan tulang) yang mengakibatkan mereka berada dalam kondisi terancam menderita osteoporosis (Minropa, 2013).

Puskesmas Kutalimbaru adalah salah satu puskesmas induk yang ada di Kabupaten Deli Serdang. Jumlah lansia yang ada di wilayah kerja Puskesmas Kutalimbaru adalah 1.827 yang tersebar di 14 desa. Data kunjungan bulan juni 2017 bahwa kunjungan lansia di Puskesmas Kutalimbaru sebanyak 156 orang atau kunjungan lansia per hari ratarata sebanyak 6-7 orang. Survei awal yang peneliti lakukan selama satu minggu untuk mengetahui keadaan lansia yang ada di Puskesmas Kutalimbaru yang mengalami osteoporosis pada bulan Juni 2017 sebanyak 28 orang $(17,9 \%)$ dan sebagian besar didominasi oleh perempuan sebanyak 22 orang $(78,6 \%)$, dan laki-laki sebanyak 6 orang $(21,4 \%)$. Berdasarkan informasi dari Kepala Puskesmas Kutalimbaru Kabupaten Deli Serdang bahwa jumlah tersebut lebih besar lagi karena sebagian lansia banyak yang tidak memeriksakan diri ke puskesmas.

\section{METODE PENELITIAN Jenis Penelitian}

Penelitian ini merupakan penelitian analitik dengan pendekatan case control atau kasus kontrol (Prihatini, 2010). Dalam penelitian ini membandingkan kebiasaan makan pasien yang mengalami osteoporosis dan pasien yang tidak mengalami osteoporosis.

\section{Lokasi dan Waktu Penelitian}

Lokasi penelitian dilakukan di Puskesmas Kutalimbaru Kecamatan Kutalimbaru Kabupaten Deli Serdang. Alasan pemilihan lokasi ini karena dari data Puskesmas Kutalimbaru terjadi peningkatan lansia yang menderita osteoporosis. Penelitian ini dilakukan mulai dengan melakukan survei awal yang dilaksanakan mulai Juni 2017, dan selesai pada bulan Juli 2017.

Dalam penelitian ini populasi dibedakan menjadi 2 (dua) kelompok populasi yaitu populasi case dan populasi control. Populasi case dalam penelitian ini adalah seluruh lansia yang berusia 6074 tahun yang menderita osteoporosis berdasarkan hasil pemeriksaan massa tulang (kategori sedang dan berat) di wilayah kerja Puskesmas Kutalimbaru Kecamatan Kutalimbaru Kabupaten Deli Serdang sebanyak 95 orang. Populasi kontrol adalah lansia berumur 60-74 tahun yang tidak menderita osteoporosis dengan jumlah sama dengan jumlah populasi kasus sebanyak 95 orang. Jumlah populasi keseluruhan adalah 190 orang.

Kelompok sampel dalam penelitian ini terdiri dari 2 (dua) kelompok yaitu kelompok case sebanyak 95 orang dan kelompok control sebanyak 95 orang. Teknik sampling yang akan digunakan untuk penarikan sampel adalah technique fixed diseases sampling yang merupakan prosedur pemilihan berdasarkan status penyakit/kasus subyek, sedangkan status paparan subyek bervariasi mengikuti status penyakit subyek yang sudah fixed (Maryam, 2011).

Uji validitas dilakukan pada 30 orang lansia di luar sampel. Butir kuesioner dinyatakan valid jika nilai r-hitung lebih besar dari r-tabel atau r-hitung $>$ r-tabel $(0,361)$ atau nilai signifikan $(\mathrm{p})<0,05$.

Hasil uji validitas menunjukkan bahwa seluruh butir soal baik variabel kebiasaan makan dinyatakan valid karena seluruhnya mempunyai nilai r-hitung 
lebih besar dibanding r-tabel atau semua butir soal mempunyai nilai $r>0,361$.

Hasil uji reliabilitas menunjukkan bahwa variabel kebiasaan makan memiliki nilai yang lebih tinggi dibandingkan batas ketentuan batas Cronbach Alpha yaitu 0,734>0,600. Nilai tersebut menunjukkan bahwa variabel kebiasaan makan dinyatakan reliabel. Selengkapnya dapat dilihat pada tabel berikut ini.

\section{HASIL PENELITIAN}

\section{Analisis Univariat}

\section{Karakteristik Responden}

\section{1) Umur}

Berdasarkan hasil penelitian, usia yang ditetapkan sebagai responden adalah lansia (eldery) yaitu berusia 60-74 tahun. Pada kelompok kasus, mayoritas responden berusia 60-65 tahun sebanyak 56 orang $(58,9 \%)$, demikian juga pada kelompok kontrol mayoritas berusia $60-$ 65 tahun sebanyak 64 orang $(67,4 \%)$. Distribusi responden berdasarkan kelompok umur dapat dilihat pada tabel berikut.

Tabel 1. Distribusi Responden Berdasarkan Umur di Puskesmas Kutalimbaru Kecamatan Kutalimbaru Kabupaten Deli Serdang Tahun 2015

\begin{tabular}{ccrrrr}
\hline \multirow{2}{*}{ No. } & \multirow{2}{*}{ Umur } & \multicolumn{2}{c}{ Kasus } & \multicolumn{2}{c}{ Kontrol } \\
\cline { 3 - 6 } & & $\mathbf{n}$ & $\mathbf{\%}$ & \multicolumn{1}{c}{ n } & \multicolumn{1}{c}{$\%$} \\
\hline 1. & $60-65$ & 56 & 58,9 & 64 & 67,4 \\
2. & $66-70$ & 30 & 31,6 & 24 & 25,2 \\
3. & $71-74$ & 9 & 9,5 & 7 & 7,4 \\
\hline \multicolumn{2}{c}{ Jumlah } & $\mathbf{9 5}$ & $\mathbf{1 0 0 , 0}$ & $\mathbf{9 5}$ & $\mathbf{1 0 0 , 0}$ \\
\hline
\end{tabular}

\section{2) Jenis Kelamin}

Berdasarkan jenis kelamin, mayoritas responden kelompok kasus adalah perempuan sebanyak 77 orang $(81,1 \%)$, demikian juga kelompok kontrol mayoritas perempuan sebanyak 59 orang $(62,1 \%)$. Distribusi frekuensi responden berdasarkan jenis kelamin sebagai berikut:
Tabel 2.Distribusi Responden

Berdasarkan Jenis Kelamin di Puskesmas Kutalimbaru Kecamatan Kutalimbaru Kabupaten Deli Serdang Tahun 2017

\begin{tabular}{llcccc}
\hline \multirow{2}{*}{ No } & \multirow{2}{*}{ Jenis } & \multicolumn{2}{c}{ Kasus } & \multicolumn{2}{c}{ Kontrol } \\
\cline { 3 - 6 } & Kelamin & $\mathbf{n}$ & $\mathbf{\%}$ & $\mathbf{n}$ & $\mathbf{\%}$ \\
\hline 1. & Laki-laki & 18 & 18,9 & 36 & 37,9 \\
2. & $\begin{array}{l}\text { Perem- } \\
\text { puan }\end{array}$ & 77 & 81,1 & 59 & 62,1 \\
\hline \multicolumn{2}{l}{ Jumlah } & $\mathbf{9 5}$ & $\mathbf{1 0 0 , 0}$ & $\mathbf{9 5}$ & $\mathbf{1 0 0 , 0}$ \\
\hline
\end{tabular}

\section{3) Pendidikan}

Berdasarkan pendidikan, mayoritas responden pada kelompok kontrol berpendidikan SD sebanyak 69 orang $(72,6 \%)$, demikian juga pada kelompok kontrol mayoritas berpendidikan SD sebanyak 72 orang (75,8\%). Distribusi frekuensi responden berdasarkan pendidikan sebagai berikut:

Tabel 3. Distribusi Responden

Berdasarkan Pendidikan di Puskesmas Kutalimbaru Kecamatan Kutalimbaru Kabupaten Deli Serdang Tahun 2017

\begin{tabular}{llcccc}
\hline \multirow{2}{*}{ No } & $\begin{array}{c}\text { Pendi- } \\
\text { dikan }\end{array}$ & \multicolumn{2}{c}{ Kasus } & \multicolumn{2}{c}{ Kontrol } \\
\cline { 3 - 6 } & n & \% & N & \% \\
\hline 1. & SD & 69 & 72,6 & 72 & 75,8 \\
2. & SMP & 23 & 24,2 & 17 & 17,9 \\
3. & SMA & 3 & 3,2 & 6 & 6,3 \\
\hline \multicolumn{2}{l}{ Jumlah } & 95 & 100,0 & 95 & 100,0 \\
\hline
\end{tabular}

\section{4) Pekerjaan}

Berdasarkan pekerjaan, mayoritas responden pada kelompok kasus tidak bekerja sebanyak 61 orang $(64,2 \%)$, demikian juga pada kelompok kontrol mayoritas tidak bekerja sebanyak 57 orang $(60 \%)$. Distribusi frekuensi responden berdasarkan pekerjaan sebagai berikut:

Tabel 4. Distribusi Responden Berdasarkan Pekerjaan di Puskesmas Kutalimbaru Kecamatan Kutalimbaru Kabupaten Deli Serdang Tahun 2017

\begin{tabular}{llcccc}
\hline \multirow{2}{*}{ No } & \multirow{2}{*}{ Pekerjaan } & \multicolumn{2}{c}{ Kasus } & \multicolumn{2}{c}{ Kontrol } \\
\cline { 3 - 6 } & & $\mathbf{n}$ & $\boldsymbol{\%}$ & $\mathbf{n}$ & $\boldsymbol{\%}$ \\
\hline 1. & Petani & 34 & 35,8 & 38 & 40,0
\end{tabular}




\begin{tabular}{llcccc}
\hline \multirow{2}{*}{ No } & \multirow{2}{*}{ Pekerjaan } & \multicolumn{2}{c}{ Kasus } & \multicolumn{2}{c}{ Kontrol } \\
\cline { 2 - 5 } & & $\mathbf{n}$ & $\mathbf{\%}$ & $\mathbf{n}$ & $\mathbf{\%}$ \\
\hline 2. & Tidak & 61 & 64,2 & 57 & 60,0 \\
bekerja & & & & \\
\hline & Jumlah & $\mathbf{9 5}$ & $\mathbf{1 0 0 , 0}$ & $\mathbf{9 5}$ & $\mathbf{1 0 0 , 0}$ \\
\hline
\end{tabular}

\begin{tabular}{llcccc}
\hline & perkawinan & $\mathbf{n}$ & $\mathbf{\%}$ & $\mathbf{n}$ & $\mathbf{\%}$ \\
\hline 1. & Menikah & 59 & 62,1 & 67 & 70,5 \\
2. & Duda & 10 & 10,5 & 11 & 11,6 \\
3. & Janda & 26 & 27,4 & 17 & 17,9 \\
\hline & Jumlah & $\mathbf{9 5}$ & $\mathbf{1 0 0 , 0}$ & $\mathbf{9 5}$ & $\mathbf{1 0 0 , 0}$ \\
\hline
\end{tabular}

\section{5) Status Perkawinan}

Berdasarkan status perkawinan, mayoritas responden pada kelompok kasus berstatus menikah sebanyak 59 orang $(62,1 \%)$, demikian juga pada kelompok kontrol mayoritas menikah sebanyak 67 orang $(70,5 \%)$. Distribusi frekuensi responden berdasarkan status perkawinan sebagai berikut:

Tabel 5. Distribusi Responden

Berdasarkan Status Perkawinan di Puskesmas Kutalimbaru Kecamatan Kutalimbaru Kabupaten Deli Serdang Tahun 2017

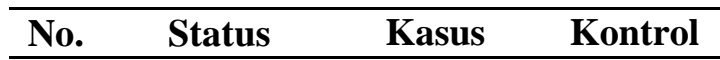

\section{Kebiasaan Makan}

\section{1) Minum Air Putih}

Berdasarkan kebiasaan minum air putih, mayoritas responden pada kelompok kasus kategori tidak berisiko sebanyak 71 orang $(37,4 \%)$, demikian juga pada kelompok kontrol kategori tidak berisiko sebanyak 80 orang $(42,1 \%)$. Hasil uji chi-square diperoleh $p$-value $=0,151>0,05$ artinya tidak ada hubungan konsumsi minum air putih dengan kejadian osteoporosis. Nilai OR diperoleh $0,555<1$ artinya minum air putih bukan merupakan faktor risiko osteoporosis. Distribusi frekuensi responden berdasarkan kebiasaan minum air putih sebagai berikut:

Tabel 6. Distribusi Responden Berdasarkan Kebiasaan Minum Air Putih di Puskesmas Kutalimbaru Kecamatan Kutalimbaru Kabupaten Deli Serdang Tahun 2017

\begin{tabular}{llccccccc}
\hline \multirow{2}{*}{ No } & \multirow{2}{*}{ Minum Air Putih } & \multicolumn{2}{c}{ Kasus } & \multicolumn{2}{c}{ Kontrol } & \multirow{2}{*}{ OR } & \multirow{2}{*}{ 95\% CI } \\
\cline { 3 - 6 } & & $\mathbf{n}$ & $\mathbf{\%}$ & $\mathbf{N}$ & $\mathbf{\%}$ & & & \\
\hline 1. & Tidak berisiko & 71 & 37,4 & 80 & 42,1 & & & \\
2. & Berisiko & 24 & 12,6 & 15 & 7,9 & 0,151 & 0,555 & $0,270-1,139$ \\
\hline & Jumlah & $\mathbf{9 5}$ & $\mathbf{5 0 , 0}$ & $\mathbf{9 5}$ & $\mathbf{5 0 , 0}$ & & & \\
\hline
\end{tabular}

\section{2) Porsi Makan}

Berdasarkan porsi makan, mayoritas responden pada kelompok kasus kategori berisiko sebanyak 60 orang $(31,6 \%)$, sedangkan pada kelompok kontrol kategori tidak berisiko sebanyak 59 orang $(61,1 \%)$. Hasil uji chi-square diperoleh $p$-value $=0,001<0,05$ artinya ada hubungan porsi makan dengan kejadian osteoporosis. Nilai OR diperoleh $0,356<1$ artinya porsi makan bukan merupakan faktor risiko osteoporosis. Distribusi frekuensi responden berdasarkan porsi makan sebagai berikut:

Tabel 7. Distribusi Responden Berdasarkan Porsi Makan di Puskesmas Kutalimbaru Kecamatan Kutalimbaru Kabupaten Deli Serdang Tahun 2015

\begin{tabular}{lcccccccc}
\hline \multirow{2}{*}{ No. } & \multirow{2}{*}{ Porsi Makan } & \multicolumn{2}{c}{ Kasus } & \multicolumn{2}{c}{ Kontrol } & \multirow{2}{*}{ OR } & \multirow{2}{*}{ 95\% CI } \\
\cline { 3 - 6 } & & $\mathbf{N}$ & $\mathbf{\%}$ & $\mathbf{n}$ & $\mathbf{\%}$ & & & \\
\hline 1. & Tidak berisiko & 35 & 18,4 & 59 & 31,1 & & & \\
2. & Berisiko & 60 & 31,6 & 36 & 18,9 & 0,001 & 0,356 & $0,198-0,641$ \\
\hline \multicolumn{2}{c}{ Jumlah } & $\mathbf{9 5}$ & $\mathbf{5 0 , 0}$ & $\mathbf{9 5}$ & $\mathbf{5 0 , 0}$ & & & \\
\hline
\end{tabular}




\section{3) Jenis Makanan yang Dikonsumsi}

Berdasarkan jenis makanan yang dikonsumsi, mayoritas responden pada kelompok kasus kategori tidak berisiko sebanyak 69 orang $(36,3 \%)$, demikian juga pada kelompok kontrol kategori tidak berisiko sebanyak 76 orang $(40,0 \%)$. Hasil uji chi-square diperoleh $\mathrm{p}=0,306>0,05$ artinya tidak ada hubungan jenis makanan yang dikonsumsi dengan kejadian osteoporosis. Nilai OR diperoleh $0,663<1$ artinya jenis makanan yang dikonsumsi bukan merupakan faktor risiko osteoporosis. Distribusi frekuensi responden berdasarkan jenis makanan yang dikonsumsi sebagai berikut:

Tabel 8. Distribusi Responden Berdasarkan Jenis Makanan yang dikonsumsi di Puskesmas Kutalimbaru Kecamatan Kutalimbaru Kabupaten Deli Serdang Tahun 2017

\begin{tabular}{llccccccc}
\hline \multirow{2}{*}{ No. } & \multirow{2}{*}{ Jenis makanan yang dikonsumsi } & \multicolumn{2}{c}{ Kasus } & \multicolumn{2}{c}{ Kontrol } & \multirow{2}{*}{ OR } & \multirow{2}{*}{$\mathbf{9 5 \%}$ CI } \\
\cline { 3 - 6 } & & $\mathbf{n}$ & $\mathbf{\%}$ & $\mathbf{n}$ & $\boldsymbol{\%}$ & & \multirow{2}{*}{ OR } & \\
\hline 1. & Tidak berisiko & 69 & 36.3 & 76 & 40.0 & & & \\
2. & Berisiko & 26 & 13.7 & 19 & 10.0 & 0,306 & 0,663 & $0,338-1,304$ \\
\hline \multicolumn{1}{c}{ Jumlah } & $\mathbf{9 5}$ & $\mathbf{5 0 , 0}$ & $\mathbf{9 5}$ & $\mathbf{5 0 , 0}$ & & & \\
\hline
\end{tabular}

\section{4) Minum Jus Buah}

Berdasarkan minum jus buah, mayoritas responden pada kelompok kasus kategori berisiko sebanyak 80 orang $(42,1 \%)$, demikian juga pada kelompok kontrol kategori berisiko sebanyak 73 orang $(38,4 \%)$. Hasil uji chi-square diperoleh $p$-value $=0,272>0,05$ artinya tidak ada hubungan minum jus buah dengan kejadian osteoporosis. Nilai OR diperoleh $0,622<1$ artinya minum jus buah bukan merupakan faktor risiko terjadinya osteoporosis. Distribusi frekuensi responden berdasarkan minum jus buah sebagai berikut:

Tabel 4.9. Distribusi Responden Berdasarkan Minum Jus Buah di Puskesmas Kutalimbaru Kecamatan Kutalimbaru Kabupaten Deli Serdang Tahun 2017

\begin{tabular}{|c|c|c|c|c|c|c|c|c|}
\hline \multirow{2}{*}{ No. } & \multirow{2}{*}{ Minum jus buah } & \multicolumn{2}{|c|}{ Kasus } & \multicolumn{2}{|c|}{ Kontrol } & \multirow[b]{2}{*}{$p$} & \multirow{2}{*}{ OR } & \multirow{2}{*}{$95 \% \mathrm{CI}$} \\
\hline & & $\mathbf{n}$ & $\%$ & $\mathbf{n}$ & $\%$ & & & \\
\hline 1. & Tidak berisiko & 15 & 7,9 & 22 & 11,6 & \multirow{3}{*}{0,272} & \multirow{3}{*}{0,622} & \multirow{3}{*}{$0,300-1,290$} \\
\hline 2. & Berisiko & 80 & 42,1 & 73 & 38,4 & & & \\
\hline & Jumlah & 95 & 50,0 & 95 & $\mathbf{5 0 , 0}$ & & & \\
\hline
\end{tabular}

\section{5) Makanan Selingan}

Berdasarkan makanan selingan, mayoritas responden pada kelompok kasus kategori berisiko sebanyak 67 orang $(35,3 \%)$, demikian juga pada kelompok kontrol kategori berisiko sebanyak 59 orang $(31,1 \%)$. Hasil uji chi-square diperoleh $p$-value $=0,283>0,05$ artinya tidak ada hubungan makanan selingan dengan kejadian osteoporosis. Nilai OR diperoleh $0,685<1$ artinya makanan selingan bukan merupakan faktor risiko osteoporosis. Distribusi frekuensi responden berdasarkan makanan selingan sebagai berikut:

Tabel 4.10. Distribusi Responden Berdasarkan Makanan Selingan di Puskesmas Kutalimbaru Kecamatan Kutalimbaru Kabupaten Deli Serdang Tahun 2017

\begin{tabular}{|c|c|c|c|c|c|c|c|c|}
\hline \multirow{2}{*}{ No. } & \multirow{2}{*}{ Makanan Selingan } & \multicolumn{2}{|c|}{ Kasus } & \multicolumn{2}{|c|}{ Kontrol } & \multirow[b]{2}{*}{$p$} & \multirow[b]{2}{*}{$\mathbf{O R}$} & \multirow{2}{*}{$95 \% \mathrm{CI}$} \\
\hline & & $\mathbf{n}$ & $\%$ & $\mathbf{n}$ & $\%$ & & & \\
\hline $\begin{array}{l}1 . \\
2 .\end{array}$ & $\begin{array}{l}\text { Tidak berisiko } \\
\text { Berisiko }\end{array}$ & $\begin{array}{l}28 \\
67 \\
\end{array}$ & $\begin{array}{l}14,7 \\
35,3\end{array}$ & $\begin{array}{l}36 \\
59 \\
\end{array}$ & $\begin{array}{l}18,9 \\
31,1\end{array}$ & 0,283 & 0,685 & $0,374-1,255$ \\
\hline
\end{tabular}




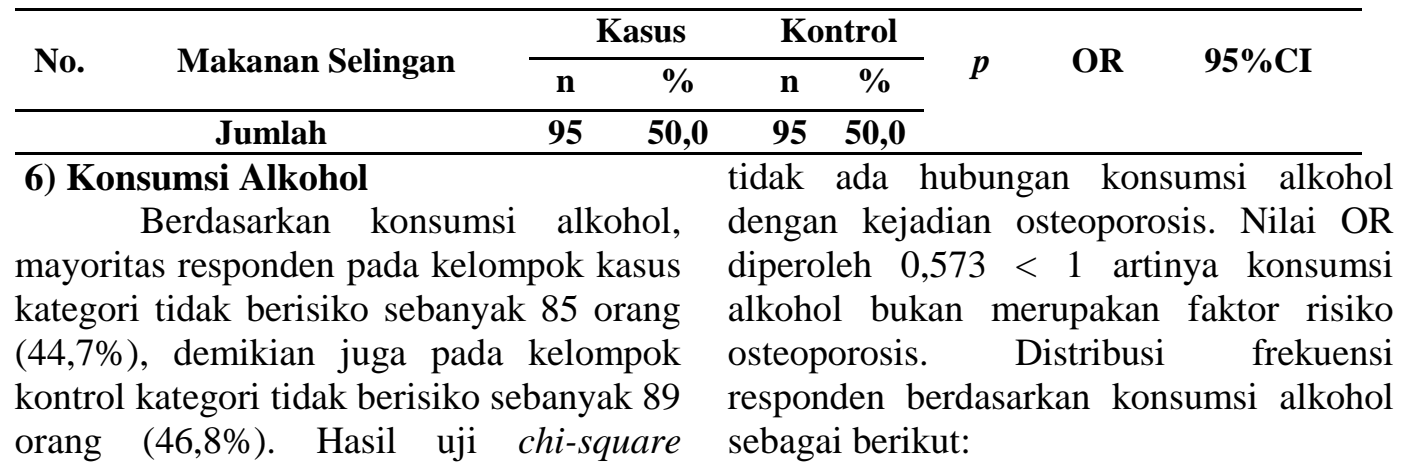
diperoleh $p$-value $=0,433>0,05$ artinya

Tabel 4.11. Distribusi Responden Berdasarkan Konsumsi Alkohol di Puskesmas Kutalimbaru Kecamatan Kutalimbaru Kabupaten Deli Serdang Tahun 2017

\begin{tabular}{|c|c|c|c|c|c|c|c|c|}
\hline \multirow{2}{*}{ No. } & \multirow{2}{*}{ Konsumsi alkohol } & \multicolumn{2}{|c|}{ Kasus } & \multicolumn{2}{|c|}{ Kontrol } & \multirow[b]{2}{*}{$p$} & \multirow[b]{2}{*}{ OR } & \multirow[b]{2}{*}{$95 \% \mathrm{CI}$} \\
\hline & & $\mathbf{n}$ & $\%$ & $\mathbf{n}$ & $\%$ & & & \\
\hline 1. & Tidak berisiko & 85 & 44,7 & 89 & 46,8 & \multirow{3}{*}{0,433} & \multirow{3}{*}{0,573} & \multirow{3}{*}{$0,200-1,646$} \\
\hline 2. & Berisiko & 10 & 5,3 & 6 & 3,2 & & & \\
\hline \multicolumn{2}{|r|}{ Jumlah } & 95 & $\mathbf{5 0 , 0}$ & \multicolumn{2}{|l|}{95} & & & \\
\hline \multicolumn{4}{|c|}{$\begin{array}{l}\text { 7) Konsumsi Susu } \\
\text { Berdasarkan konsumsi susu, } \\
\text { mayoritas responden pada kelompok kasus } \\
\text { kategori berisiko sebanyak } 75 \text { orang } \\
(39,5 \%) \text {, demikian juga pada kelompok }\end{array}$} & \multicolumn{5}{|c|}{$\begin{array}{l}\text { diperoleh } p \text {-value }=0,025<0,05 \text { artinya } \\
\text { ada hubungan konsumsi susu dengan } \\
\text { kejadian osteoporosis. Nilai OR diperoleh } \\
0,457<1 \text { artinya konsumsi susu bukan } \\
\text { merupakan faktor risiko osteoporosis. } \\
\text { Distribusi frekuensi responden berdasarkan } \\
\text { konsumsi susu sebagai berikut: }\end{array}$} \\
\hline
\end{tabular}

orang (31,6\%). Hasil uji chi-square

Tabel 4.12.Distribusi Responden Berdasarkan Konsumsi Susu di Puskesmas Kutalimbaru Kecamatan Kutalimbaru Kabupaten Deli Serdang Tahun 2017

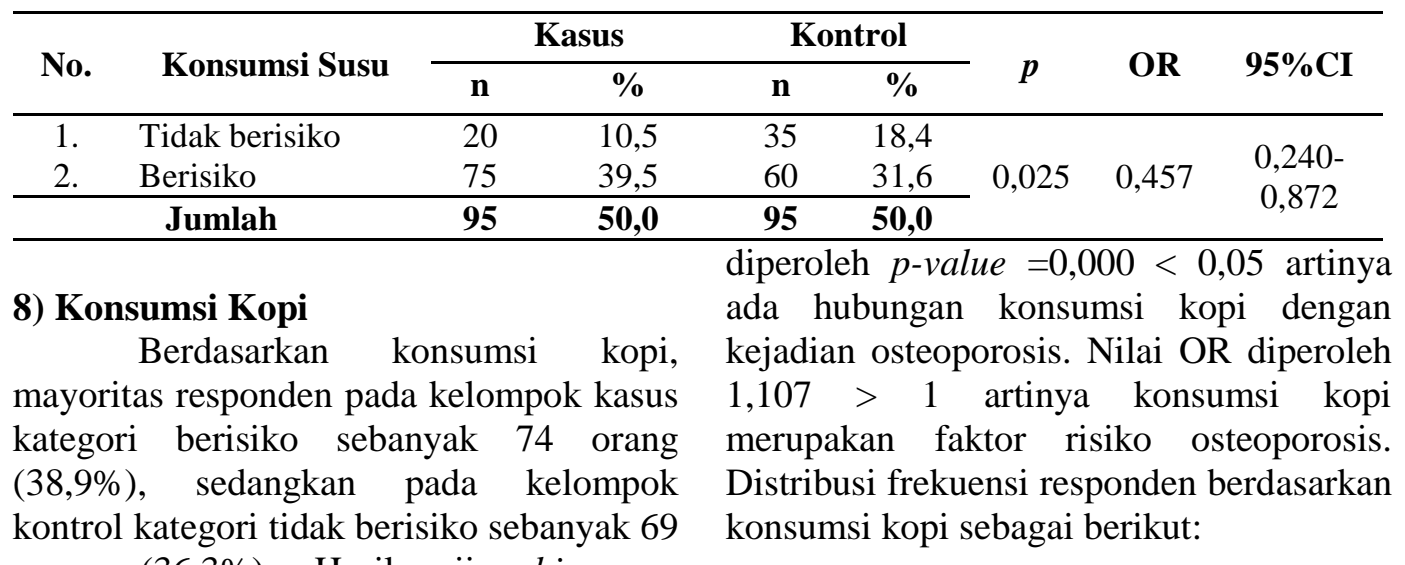
orang (36,3\%). Hasil uji chi-square

Tabel 4.13.Distribusi Responden Berdasarkan Konsumsi Kopi di Puskesmas Kutalimbaru Kecamatan Kutalimbaru Kabupaten Deli Serdang Tahun 2017

\begin{tabular}{|c|c|c|c|c|c|c|c|c|}
\hline \multirow[b]{2}{*}{ No. } & \multirow{2}{*}{ Konsumsi Kopi } & \multicolumn{2}{|c|}{ Kasus } & \multicolumn{2}{|c|}{ Kontrol } & \multirow[b]{2}{*}{$p$} & \multirow{2}{*}{ OR } & \multirow{2}{*}{$95 \% \mathrm{CI}$} \\
\hline & & $\mathbf{n}$ & $\%$ & $\mathbf{n}$ & $\%$ & & & \\
\hline 1. & Tidak berisiko & 21 & 11,1 & 69 & 36,3 & \multirow{3}{*}{0,000} & \multirow{3}{*}{1,407} & \multirow{3}{*}{$1,055-2,807$} \\
\hline 2. & Berisiko & 74 & 38,9 & 26 & 13,7 & & & \\
\hline & Jumlah & 95 & 50,0 & 95 & 50,0 & & & \\
\hline
\end{tabular}




\section{9) Konsumsi Sayuran Hijau}

Berdasarkan konsumsi sayuran hijau, mayoritas responden pada kelompok kasus kategori berisiko sebanyak 72 orang (37,9\%), demikian juga pada kelompok kontrol kategori berisiko sebanyak 48 orang $(25,3 \%)$. Hasil uji chi-square diperoleh $p$-value $=0,001<0,05$ artinya

Tabel 4.14 Distribusi Responden Berdasarkan Konsumsi Sayuran Hijau di Puskesmas Kutalimbaru Kecamatan Kutalimbaru Kabupaten Deli Serdang Tahun 2017

\begin{tabular}{llccccccc}
\hline \multirow{2}{*}{ No. } & \multirow{2}{*}{ Konsumsi Sayuran Hijau } & \multicolumn{2}{c}{ Kasus } & \multicolumn{2}{c}{ Kontrol } & \multirow{2}{*}{ OR } & \multirow{2}{*}{ 95\%CI } \\
\cline { 3 - 6 } & $\mathbf{n}$ & $\mathbf{\%}$ & $\mathbf{n}$ & $\mathbf{\%}$ & & & \\
\hline 1. & Tidak berisiko & 23 & 12,1 & 47 & 24,7 & & & \\
2. & Berisiko & 72 & 37,9 & 48 & 25,3 & 0,001 & 1,326 & $1,176-2,605$ \\
\hline & Jumlah & $\mathbf{9 5}$ & $\mathbf{5 0 , 0}$ & $\mathbf{9 5}$ & $\mathbf{5 0 , 0}$ & & & \\
\hline
\end{tabular}

\section{0) Konsumsi Buah Segar}

Berdasarkan konsumsi buah segar, mayoritas responden pada kelompok kasus kategori berisiko sebanyak 70 orang $(36,8 \%)$, demikian juga pada kelompok kontrol kategori berisiko sebanyak 54 orang $(28,4 \%)$. Hasil uji chi-square ada hubungan konsumsi sayuran hijau dengan kejadian osteoporosis. Nilai OR diperoleh $1,326>1$ artinya konsumsi sayuran hijau merupakan faktor risiko osteoporosis. Distribusi frekuensi responden berdasarkan konsumsi sayuran hijau sebagai berikut: diperoleh $p$-value $=0,022<0,05$ artinya ada hubungan konsumsi buah segar dengan kejadian osteoporosis. Nilai OR diperoleh $0,470<1$ artinya konsumsi buah segar bukan merupakan faktor risiko osteoporosis. Distribusi frekuensi responden berdasarkan konsumsi buah segar sebagai berikut:

Tabel 4.15. Distribusi Responden Berdasarkan Konsumsi Buah Segar di Puskesmas

Kutalimbaru Kecamatan Kutalimbaru Kabupaten Deli Serdang Tahun 2017

\begin{tabular}{cccc}
\hline \multirow{2}{*}{ No. } & \multirow{2}{*}{ Konsumsi Buah Segar } & \multicolumn{2}{c}{ Kasus } \\
\cline { 3 - 4 } & & $\mathbf{n}$ & $\mathbf{\%}$ \\
\hline 1. & Tidak berisiko & 25 & 13 \\
2. & Berisiko & 70 & 36 \\
\hline \multicolumn{2}{c}{ Jumlah } & $\mathbf{9 5} \quad \mathbf{5 0}$ \\
\hline & & \\
Analisis Multivariat & \\
\multicolumn{2}{c}{ Untuk mengetahui } & faktor-faktor \\
yang berhubungan dengan & osteoporosis \\
pada lansia di Kecamatan & Kutalimbaru \\
$\begin{array}{l}\text { Kabupaten Deli Serdang secara bersamaan } \\
\text { dilakukan analisis }\end{array}$ & multivariat
\end{tabular}
menggunakan uji regresi logistik berganda (multiple logistic regression) melalui beberapa langkah yaitu:

1) Memilih variabel yang potensial dimasukkan dalam model. Variabel yang dipilih sebagai kandidat atau yang dianggap signifikan yang memiliki nilai $p$-value $<0,25$ pada uji bivariat selanjutnya dimasukkan secara bersama-sama dalam uji multivariat. 
sehari-hari lansia yang berhubungan signifikan dengan kejadian osteoporosis di Puskesmas Kutalimbaru Kecamatan Kutalimbaru Kabupaten Deli Serdang yaitu porsi makan $(p=0,005$, OR $=$ $3,374)$, konsumsi kopi ( $p=0,000$, OR $=$ $4,116)$, dan konsumsi sayuran hijau ( $p=$ $0,013$, OR $=2,399)$. Variabel yang tidak berhubungan dengan osteoporosis pada lansia adalah minum air putih ( $p=$ $0,512)$, konsumsi susu $(p=0,094)$, dan konsumsi buah segar ( $p=0,385)$.

Variabel yang paling besar berhubungan dengan osteoporosis pada lansia di Kecamatan Kutalimbaru Kabupaten Deli Serdang yaitu konsumsi kopi. Lansia yang sering mengonsumsi kopi berpeluang mengalami osteoporosis sebesar 4,1 kali lebih tinggi dibandingkan dengan lansia yang jarang atau tidak pernah mengonsumsi kopi.

\section{Saran}

1) Puskesmas Kutalimbaru

(1) Disarankan kepada Puskesmas Kutalimbaru untuk memberikan penyuluhan atau promosi kesehatan tentang keluarga sadar gizi (kadarzi) pada masyarakat dengan sasaran lansia melalui kegiatan-kegiatan kemasyarakatan seperti perwiritan, perpulungan, atau arisan keluarga sehingga pengetahuan masyarakat meningkat dan lansia dapat diperhatikan keadaan gizinya serta kebiasaan makannya menjadi lebih baik.

(2) Memberdayakan keluarga dalam upaya peningkatan status gizi keluarga dan pemahaman tentang gejala terjadinya osteoporosis pada lansia melalui pembagian brosur atau leaflet yang mudah dipahami dan dimengerti oleh lansia sehingga dapat dideteksi sejak dini lansia yang mengalami gejala osteoporosis.

(3) Membagikan susu atau makanan dengan kandungan kalsium tinggi kepada lansia melalui kegiatan posyandu lansia.

2) Lansia

Disarankan kepada lansia lebih memperhatikan asupan gizi dan kebiasaan makan sehari-hari dengan menghindari kebiasaan minum alkohol, makan tepat waktu, jumlah takaran yang tepat, mengonsumsi sayuran hijau secara rutin, mengonsumsi buah segar, mengonsumsi susu dan makanan yang mengandung tinggi kalsium lainnya.

\section{DAFTAR PUSTAKA}

Badan Pusat Statistik (BPS). 2014. Data penduduk umur 60 tahun ke atas menurut provinsi berdasarkan keadaan kesehatan. Jakarta: Badan Pusat Statistik.

Dalimartha S. 2009. Resep tumbuhan obat untuk penderita osteoporosis. Cetakan I, Jakarta : Penebar Swadaya.

Hartono M. 2010. Mencegah dan mengatasi osteoporosis. Cetakan I. Jakarta: Puspa Swara.

Hasibuan W. 2006. Hubungan Program Pelayanan Posyandu Lansia terhadap tingkat kepuasan lansia di daerah Binaan Puskesmas Darussalam Medan. Jurnal Keperawatan Rufaidah Sumatera Utara.

Kasdu D. 2001. Kiat sehat dan bahagia di usia menopause, Cetakan I, Jakarta: Puspa Swara.

Komnas Lansia. 2010. Buku pedoman lansia. Jakarta: Komisi Nasional Lanjut Usia.

Marjan AQ. 2013. Hubungan antara pola konsumsi pangan dan aktivitas fisik dengan kejadian osteoporosis pada lansia di panti Werdha Bogor. Jurnal Gizi dan Pangan.

Maryam RS. 2011. Mengenal usia lanjut dan perawatannya. Jakarta : Salemba Medika 13.Marjan AQ. Hubungan antara pola konsumsi pangan dan aktivitas fisik dengan kejadian osteoporosis pada lansia di panti werdha Bogor. Jurnal Gizi dan 
Pangan, 2013; 8(2): 123-128. 14. Ahdaniar A. Faktor yang berhubungan dengan kejadian penyakit rematik pada lansia di wilayah Puskesmas Kassi-Kassi Kota Makassar. Jurnal Ilmiah

Minropa A. 2013. Faktor-faktor yang berhubungan dengan risiko osteoporosis pada lansia di Kenagarian Api-Api Wilayah Kerja Puskesmas Pasar Baru Kecamatan Bayang Kabupaten Pesisir Selatan tahun 2013. Padang: STIKes Mercubaktijaya.

Murti B. 2010. Desain studi Institute of health economic and policy studies (IHEPS). Solo: Bagian Ilmu Kesehatan Masyarakat Fakultas Kedokteran Universitas Sebelas Maret.

Mulyani EY. 2013. Osteoporosis, konsumsi susu, jenis kelamin, umur dan daerah di DKI Jakarta, Jawa Barat, Jawa Tengah dan Jawa Timur, JGP.
Pratama, M.Y. 2017. Analisis Kualitas Kehidupan Kerja Perawat Pelaksana di Rumah Sakit Putri Hijau Medan. Jurnal Ilmiah Penelitian Kesehatan (Jumantik).

http://www.jurnal.uinsu.ac.id/index.ph p/kesmas/article/view/1192, tanggal akses 20 Desember 2017.

Prihatini S. 2010. Faktor determinan risiko osteoporosis di tiga provinsi di Indonesia. Media Litbang Kesehatan. 2010; XX(2).

Tami DR. 2012. Hubungan pola makan, status gizi, dan interaksi sosial dengan kualitas hidup lansia di Kecamatan Tamalanrea. Makassar: Fakultas Kesehatan Masyarakat Universitas Hasanuddin; 2012.

Wardhana W. 2012. Faktor-faktor risiko osteoporosis pada pasien dengan usia di atas 50 tahun. Semarang: Fakultas Kedokteran Universitas Diponegoro. 